\title{
A diferença ontológica entre o devido processo legal, o contraditório e a ampla defesa sob o enfoque da Constituição Federal e das leis da República Brasileira
}

The ontological difference between due process, contradictory and broad defense under the focus of the Federal Constitution and the laws of the Brazilian Republic

La diferencia ontológica entre el debido proceso, la defensa contradictoria y amplia bajo el enfoque de la Constitución Federal y las leyes de la República Brasilenã

\author{
Achibaldo Nunes dos Santos \\ ORCID: https://orcid.org/0000-0002-5046-5928 \\ Universidade Paranaense, Brasil \\ E-mail: alchionunsan@gmail.com \\ Bruno Smolarek Dias \\ ORCID: https://orcid.org/0000-0001-9998-7025 \\ Universidade Paranaense, Brasil \\ E-mail: professorbruno@unipar.br \\ Jônatas Luiz Moreira de Paula \\ ORCID: https://orcid.org/0000-0001-6408-0394 \\ Universidade Paranaense, Brasil \\ E-mail: jlmp@ prof.unipar.br
}

\begin{abstract}
Resumo
$\mathrm{Na}$ seara jurídico-processual, deve-se observar toda a estrutura de princípios estampados no texto da Constituição Federal brasileira, particularmente os enunciados alçados ao patamar de direitos humanos, incorporados pelo ordenamento pátrio e concebidos a partir do aspecto de direitos fundamentais, que hão de reger todo o arcabouço de relações jurídico-sociais, tendo em conta a universalidade de tais preceitos e a garantia de acesso à justiça. Desse contexto de princípios-norma, três deles se destacam, a saber, o devido processo legal, o contraditório e a ampla defesa. Todavia, no pragmatismo jurídico cotidiano, percebe-se que pouca atenção é metodicamente direcionada à distinção entre tais enunciados, em especial no que toca ao contraditório e à ampla defesa, tendo em vista a própria disposição textual constitucional, que os aloca em redação fundamental e conjunta. Portanto, a partir da metodologia científica de caráter qualitativo, amparada em revisão bibliográfica, realizada precipuamente por análise doutrinária e jurisprudencial, tem o presente artigo o objetivo de apresentar as diretrizes que evidenciam a diferença ontológica entre o devido processo legal, o contraditório e a ampla defesa, conforme as orientações provenientes da reflexão jurídica dos intérpretes e aplicadores do direito positivo, considerando-se a necessidade constitucional de compreensão unitária dos preceitos do Texto Maior brasileiro.
\end{abstract}

Palavras-chave: Constituição Federal; Princípios fundamentais; Devido processo legal; Contraditório; Ampla defesa.

\begin{abstract}
In the legal-procedural area, one must observe the entire structure of principles stamped in the text of the Brazilian Federal Constitution, particularly those listed to the level of human rights, incorporated by the national order and conceived from the aspect of fundamental rights, which will govern the entire framework of legal and social relations, taking into account the universality of such precepts and the guarantee of access to justice. In this context of standard principles, three of them stand out, namely due process, contradictory and broad defense. However, in everyday legal pragmatism, it is perceived that little attention is methodically directed to the distinction between such statements, especially with regard to contradictory and broad defense, in view of the constitutional textual disposition itself, which allocates them in a fundamental and joint writing. Therefore, based on the qualitative scientific methodology, based on a bibliographic review, carried out foremostly by doctrinal and jurisprudential analysis, this article has the objective of presenting the guidelines that evidence the ontological difference between due process, contradictory and broad defense, according to the guidelines derived from the legal reflection of interpreters and applicators of positive law, considering the constitutional need for unitary understanding of the precepts of the Brazilian Major Text.
\end{abstract}

Keywords: Federal Constitution; Fundamental principles; Due process; Contradictory; Wide defense.

\section{Resumen}

En el ámbito jurídico-procesal, se debe observar toda la estructura de principios estampados en el texto de la Constitución Federal brasileña, en particular los enumerados al nivel de los derechos humanos, incorporados por el 
orden nacional y concebidos desde el aspecto de los derechos fundamentales, que regirán todo el marco de las relaciones jurídicas y sociales, teniendo en cuenta la universalidad de tales preceptos y la garantía de acceso a la justicia. En este contexto de principios estándar, se destacan tres de ellos, a saber, el debido proceso, la defensa contradictoria y amplia. Sin embargo, en el pragmatismo jurídico cotidiano, se percibe que se presta poca atención metódicamente a la distinción entre tales afirmaciones, especialmente en lo que respecta a la defensa contradictoria y amplia, en vista de la propia disposición textual constitucional, que las asigna en una escritura fundamental y conjunta. Por lo tanto, con base en la metodología científica cualitativa, basada en una revisión bibliográfica, realizada de manera precinta por análisis doctrinal y jurisprudencial, este artículo tiene el objetivo de presentar los lineamientos que evidencian la diferencia ontológica entre el debido proceso, la defensa contradictoria y la amplia, de acuerdo con los lineamientos derivados de la reflexión jurídica de intérpretes y aplicadores del derecho positivo, considerando la necesidad constitucional de una comprensión unitaria de los preceptos del Texto Mayor brasileño.

Palabras clave: Constitución Federal; Principios fundamentales; Debido proceso; Contradictorio; Amplia defensa.

\section{Introdução}

É preciso que se diga, de início, que o princípio do devido processo legal em suas dimensões formal e substancial difere, em muito, dos princípios do contraditório e da ampla defesa, notadamente sobre os seus correspondentes espectros de proteção na ambiência administrativa e na judicial, apesar de guardarem entre si estreita relação de interligação e complementariedade, e, ainda, que essa diferença é perceptível por meio das normas jurídicas no plano estritamente legal que, sem transbordarem da moldura genérica traçada e preestabelecida pela Carta Política do Brasil, fixam-nos e definem-nos em lei do respectivo ente federativo em sua competência legislativa concorrente ou suplementar (Arts. 24, inc. XI, e 30, inc. II, da CRFB/1988).

Registre-se que, à luz da textualidade do artigo $5^{\circ}$, incs. LIV e LV, da Carta Magna Nacional, as garantias fundamentais do devido processo legal, do contraditório e da ampla defesa são indispensáveis à privação da liberdade ambulatorial ou dos bens imóveis, móveis, incorpóreos e intelectuais e, mais disso, devem ser asseguradas aos litigantes, em processo judicial ou administrativo, e aos acusados em geral, com os meios e recursos inerentes. Por conseguinte, o caráter fundamental desses direitos, a despeito da função complementar e interdependente que ambos os dispositivos constitucionais exercem, guardam distinções pontuais, ressaltadas por apontamentos técnico-jurídicos, tanto da construção doutrinária, quanto as anotações oriundas de posicionamentos jurisprudenciais, na medida em que, não obstante o cidadão seja o destinatário concreto de tais direitos, a compreensão desses enunciados, a princípio, passa pela atividade cognitiva dos julgadores incumbidos legitimamente da tarefa judicante.

A par do irrecusável consenso doutrinário e jurisprudencial em torno dessas franquias constitucionais, é certo que o alcance concreto não se limita aos litigantes, em processo judicial ou administrativo, mas abrange, também, aos acusados em geral ou interessados, inclusive na ambiência da administração pública direta e indireta de qualquer dos Poderes da União, dos Estados, do Distrito Federal e dos Municípios, pois, em suas múltiplas projeções, refletem, entre outras consequências jurídicopositivas, a indispensabilidade de prévia instauração de sindicância investigatória ou inquisitorial ou de processo administrativo disciplinar ou processo judicial à aplicação de qualquer ato punitivo que se qualifique como revestido de validade ético-jurídica, com o qual se visa garantir o correto exercício desses e dos demais direitos fundamentais do acusado, e, sobretudo, impedir eventual desprezo estatal pelos bens do cidadão nacional ou estrangeiro, porquanto não se pode desconsiderar que a majestade da Constituição Federal jamais poderá subordinar-se à potestade do Estado (e dos seus agentes) no desempenho da atividade disciplinar ou penal.

\section{Metodologia}

Para este artigo, utilizou-se a metodologia chamada revisão de bibliografia, consistente numa pesquisa natureza qualitativa. Assim, “como o próprio nome indica, analisamos as mais recentes obras científicas disponíveis que tratem do 
assunto ou que deem embasamento teórico e metodológico para o desenvolvimento da pesquisa. É aqui também que são explicitados os principais conceitos e termos técnicos [...]" (Prodanov \& Freitas, 2013, p. 131).

Desse modo, partiu-se da consulta a doutrinas jurídicas especializadas no estudo do direito (processual) constitucional como ferramenta necessária ao entendimento dos atuais posicionamentos jurisprudenciais a respeito da temática proposta, qual seja, a distinção sistemática entre os princípios do devido processo legal, do contraditório e da ampla defesa, em vista da usual utilização equivocada de tais conceitos na prática jurídica, ambiente no qual esses direitos são lançados indistintamente quando da construção de estratégias de argumentação técnica, especialmente com relação aos direitos ao contraditório e à ampla defesa.

No âmbito eminentemente jurídico, essa metodologia de pesquisa se justifica em razão de que "será produzida a partir de diferentes fontes. No Direito, temos como principais fontes a doutrina, a jurisprudência, os informativos, o contrato, o costume, a equidade e o princípio da analogia" (Mello, 2017, p. 61). A propósito, neste trabalho, o principal objeto de análise metódica se trata de temática relacionada a princípios jurídico-constitucionais, de modo que se explicita a necessidade de se efetivar uma distinção pedagógica entre esses institutos à luz da doutrina (bibliografia) e, especialmente, do arcabouço jurisprudencial pátrio.

\section{Resultados e Discussão}

\subsection{A diferença dos espectros de proteção das garantias fundamentais do devido processo legal, do contraditório e da ampla defesa no ordenamento jurídico brasileiro}

De plano, deve-se assentar o entendimento de que, contemporaneamente, o conceito que se adota de contraditório é aquele em que se contempla a "dimensão tridimensional, por ser a que melhor atende aos anseios de consolidação e fortalecimento do Estado Democrático de Direito. A tridimensionalidade do contraditório consiste nos direitos de manifestação, de informação e de ver as questões e argumentos respondidos pelo julgado" (Jayme, 2014, p. 336). Aliás, tal princípio "deve ser entendido de maneira ampla, na qualidade de atuação positiva da parte em todos os passos do processo, influindo diretamente em quaisquer aspectos, - sejam fatos, provas, pedidos da outra parte -, que sejam importantes para a decisão do conflito" (Freide, 2014, p. 113).

Impõe-se ter presente, agora, um outro aspecto que se afigura relevante, considerado o sistema normativo interno, a jurisprudência consolidada do Colendo Supremo Tribunal Federal e a do Egrégio Superior Tribunal de Justiça e as construções doutrinárias, como a de Mendes (2012), para estabelecer, aqui, o significado e o alcance normativo do princípio do devido processo legal e os do princípios do contraditório e da ampla defesa, inscritos, respectivamente, nos incisos LIV e LV do artigo $5^{\circ}$ do Texto Fundamental, os quais apenas fixam os princípios gerais, pois, os detalhamentos vão para as leis ordinárias que, de modo substancial, os distinguem e os classificam como fundamentos legais autônomos, porém, complementares e não excludentes entre si, eis que, segundo a teoria do diálogo das fontes (Arts. $1^{\circ}$ e 15 do CPC/2015), o Direito federal infraconstitucional e constitucional deve ser interpretado como um todo de forma sistemática e coordenada, ante a pluralidade de fontes normativas materiais e processuais, como exigência de um sistema jurídico coerente (Brasil, 2019b); como bem já lecionou o jurista Carlos Velloso, em sede de agravo de instrumento (Brasil, 2002a, p. 37): "É que devido processo legal-CF, art. $5^{\circ}$, LV - exerce-se de conformidade com a lei”; ou, dito de outro modo, também em sede de agravo, conforme Brasil (1995), deve ser exercido em conformidade com o procedimento estabelecido em lei, inclusive porque tais dispositivos legais possuem campos de aplicação convergentes.

Adicione-se, por necessário, após cuidadosa análise e em acertadas considerações doutrinárias e jurisprudenciais dessas Cortes de Sobreposição (STF e STJ), que é fácil inferir, sob tal perspectiva, conforme apregoa Wambier (2005, p. 73), que "[...] o devido processo legal tem significado mais restrito e tradicional, tanto que o conceitua unicamente como o processo 
cujo procedimento e cujas consequiências tenham sido previstas na lei". E, assim sendo, nas lições de Tucci (1993, p. 468), por certo que o devido processo legal tem por viés "[...] a consecução dos direitos denominados fundamentais através da efetivação do direito ao processo, materializado num procedimento regularmente desenvolvido, com a imprescindível concretização de todos os seus respectivos corolários, e num prazo razoável”.

Nessa linha de raciocínio, tratar-se o princípio do devido processo legal e os princípios do contraditório e da ampla defesa - ainda que guardem estreitas relações entre si - de institutos jurídicos diferentes e de natureza díspar, embora, de modo estrito, os desdobramentos normativos, os contornos e as consequências jurídico-positivas decorrentes dos respectivos incisos LIV e LV do artigo $5^{\circ}$ do Texto Magno Constitucional estejam em estreita conexão, eis que estes são dimensões elementares daquele, o que, aliás, encontra, de há muito, ressonância na voz autorizada do Colendo Supremo Tribunal Federal, uma vez que "iguais oportunidades de participação entre os interessados é elemento essencial do processo e imprescindível para assegurar o acesso à ordem jurídica justa e a legitimidade do processo de produção dos atos decisórios” (Jayme, 2014, p. 336).

Ademais, nesse exato sentido, vale ressaltar que a distinção básica de conteúdo entre o princípio do devido processo legal e os princípios do contraditório e da ampla defesa, além da capitulação legal e constitucional, também se consubstancia, cada um deles, na instauração de sindicância investigatória ou inquisitorial, de processo administrativo disciplinar ou judicial e na amplitude de defesa inerente as respectivas fases processuais, a comprovar que "a ampla defesa, não se a pode visualizar de modo restrito. Engloba todas as fases processuais, inclusive as recursais de natureza extraordinária" (Brasil, 2010a). E, mais disso, que essas franquias constitucionais deverão ser asseguradas, sempre, "[...] debaixo do devido processo legal, a incorporar as garantias do contraditório e da ampla defesa e, afinal, acolhida, na sua robustez, por uma sentença penal [...]” (Brasil, 2010a).

É preciso ter em conta que, nesse diálogo entre direitos fundamentais atinentes ao direito de defesa, "o direito de ser ouvido pelo juiz se opera não só mediante o confronto das partes, mas, também, por meio do dever atribuído ao magistrado de propiciar a influência dos atores processuais nas decisões tomadas, deixando-se influir" (Oliveira, 2020, p. 21). Por essa razão, há de se frisar "a necessidade de defensor, para a formalização do processo legal, como sendo a necessidade de advogado, com conhecimento técnico, que torne o contraditório uma luta igual entre acusação e defesa" (Cintra Júnior, 2012, p. 96). Todavia, também é imperioso anotar que a "defesa meramente formal fere a essência do contraditório e torna o réu substancialmente indefeso. E a solução que se impõe quando isto ocorre sem que o juiz tenha tomado providência é, mesmo, anular-se o processo" (Lopes, 1996, p. 563).

Evidencia-se, desse modo, que sem a abertura de qualquer procedimento investigatório não há que se falar em devido processo legal, o que, em si e por si, comprova, a um só tempo, a manifesta relação de ascendência desse princípio e a de submissão desses princípios corolários ou consectários, os quais, a olhos gerais, são institutos jurídicos distintos e autônomos entre si, inclusive os respectivos incisos LIV e LV do artigo $5^{\circ}$ da Carta Federal, em face da univocidade dos seus núcleos essenciais, não abrem campo a controvérsias semânticas, pois, "segundo o princípio da unidade da Constituição, o texto deve ser interpretado em sua totalidade, de forma a extirpar antinomias (contradições) entre seus preceitos” (Brasil, 2020b).

\subsection{A base legal e constitucional das garantias fundamentais de devido processo legal, do contraditório e da ampla defesa}

Vale notar, sob tal enfoque, que, além da capitulação legal e constitucional, utilidade e destinação diversas e autônomas, há, como já dito, notória diferença intrínseca e ontológica entre o sobreprincípio do devido processo legal (Inc. LIV do art. $5^{\circ}$ da CRFB/1988) e os princípios do contraditório e da ampla defesa (Inc. LV do art. $5^{\circ}$ da CRFB/1988), a qual, de modo imediato, é perceptível por meio das normas jurídicas no plano legal, que, sem transbordarem da linha mestra traçada e preestabelecida pela Carta Política do Brasil, de 1988, conforme o que se consignou em Brasil (2019a) como "O princípio 
geral que norteia a repartição de competência entre os entes componentes do Estado Federal brasileiro, [...]" , fixam-nos e definem-nos em lei do respectivo ente subnacional em sua autonomia nomológica (Arts. 24, inc. XI, e 30, inc. II, da CRFB/1988), nomeadamente no artigo 18, incs. IV e V, do Decreto-Lei n ${ }^{\circ}$ 667/1969; artigo 59 da Lei Federal no 7.210/1984; artigo 143 da Lei Federal $n^{\circ}$ 8.112/1990; artigos 86, $\S 2^{\circ}$, e 87, $\S \S 2^{\circ}$ e $3^{\circ}$, da Lei Federal $n^{\circ}$ 8.666/1993; artigo 10 da Lei Federal $n^{\circ}$ 8.745/1993; artigos $1^{\circ}$, caput, e $2^{\circ}$, caput, da Lei Federal $n^{\circ}$ 9.784/1999; artigo $8^{\circ}$, caput, da Lei Federal $n^{\circ}$ 12.846/2013; e artigo $2^{\circ}$, parágrafo único, da Lei Federal n ${ }^{\circ} 12.990 / 2014$, embora seja certo que o sobreprincípio do devido processo legal procedimental ou substancial, por seu caráter estruturante - traz em seu bojo a síntese de uma ideia primordial na ordem jurídica nacional -, tenha nos princípios do contraditório e da ampla defesa um de seus vetores fundamentais ou uma de suas específicas projeções concretizadoras na dimensão formal.

A partir de tal lógica, é inquestionável que a distinção entre a destinação desses postulados essenciais é diversa entre si e o é, segundo Brasil (2011, p. 161), “[...] porque eles são exercidos e observados nos termos da lei processual”; eis que, consoante princípio basilar de que a lei não contém palavras inúteis, insculpido no brocardo verba cum effectu sunt accipienda, afigura-se convincente, nesse aspecto, o autorizado magistério jurisprudencial do Supremo Tribunal Federal de que:

Como não se pode atribuir ao legislador, especialmente ao constitucional, a inserção, em texto de lei, de vocábulos inúteis, sem o significado vernacular que lhe é próprio, exsurge, ao menos ao primeiro exame, que a garantia do contraditório e da ampla defesa não mais está limitada, nos processos administrativos e judiciais, aos acusados, alcançando nos três campos - administrativo, civil e penal - aos litigantes em geral. (Brasil, 2014, p. 6).

Isso porque, como é de conhecimento público, "sendo o Direito uma verdadeira ciência, impossível é confundir institutos, expressões e vocábulos, sob pena de prevalecer a babel” (Brasil, 2009, p. 1058). Essa compreensão do tema - cabe ressaltar - é apoiada por autorizado magistério doutrinário da Ilustre Procuradora de Justiça Maria Rosynete de Oliveira Lima, Membro do Ministério Público do Distrito Federal e Territórios (MPDFT), em elucidativas palavras, cuja lição, reflete-se, por igual, na antiga, mas sempre contemporânea orientação jurisprudencial dos Tribunais de Superposição (STF e STJ):

Comumente encontramos nos textos jurídicos brasileiros o atrelamento do princípio do devido processo legal a outro enunciado principiológico, como, por exemplo, devido processo legal e contraditório. Este fato, por vezes justificável, é em sua maioria fruto de conclusões apressadas, já que desprezam a força normativa dos princípios envolvidos, os quais, por si sós, podem justificar resoluções jurídicas. [...] os princípios do contraditório, da ampla defesa, do juiz natural, e outros, não são corolários, deduções, ou conseqüências do princípio do devido processo legal, mas princípios, que têm um grau de concretização mais elevado e que são chamados a concretizar o devido processo legal; daí chamá-los de subprincípios, e não subespécies do devido processo legal. [...] O devido processo legal, como princípio a ser concretizado assumiria a função de uma "idéia directiva", segundo escólio de Karl Larenz (1989:579), indicando a direção aos subprincípios e lhes servindo de base. Esta diretiva não tem, contudo, mão única, mas um sentido duplo: "o princípio esclarece-se pelas suas concretizações, e estas pela sua união perfeita com o princípio". (Lima, 1999, p. 180-181).

É de ver, aliás, sob esse enfoque, que a jurisprudência sedimentada do Supremo Tribunal Federal tem sido infensa a todo e qualquer ensaio de entendimento restritivo do papel metajurídico do postulado essencial do devido processo legal, inclusive, para não ir além, o próprio inciso LIV do artigo $5^{\circ}$ da Carta Maior não foi óbice à promulgação de leis federais que o embasam no plano legal - leis posteriores ou recepcionadas - e o distinguem, com clareza solar, de outros corolários consequências -, entre os quais, os das franquias constitucionais do contraditório e da ampla defesa (Inc. LV do Art. $5^{\circ}$ da CRFB/1988), sendo, por tal razão, vedado deixar de aplicar uma lei federal por divergência doutrinária, pois, se uma lei de direito processual ou material que os distinguir e os especificar, por sua parte, não consagrou a melhor doutrina, nem por isso, o Magistrado poderá deixar de aplicá-la com lealdade e isenção, sob pena de esvaziar-se a garantia afetada, inclusive "[...] porque não é lícito ao intérprete distinguir onde o legislador não distinguiu” (Brasil, 1973, p. 281). 
Avulta enfatizar, no entanto, que os espaços de discricionariedade judicial, quando admitidos, supõem, portanto, no Estado de direito, a insuficiência ou insatisfação semântica da norma, ou seja, a presença na lei de antinomias, o que, de modo algum, é o caso do inciso LIV do artigo $5^{\circ}$ da Constituição da República, por isso mesmo, qualquer tendência hermenêutica de esvaziar de densidade normativa a garantia fundamental do devido processo legal, traduz, também, procedimento contrário aos princípios gerais de direito universalmente reconhecidos, não podendo o Estado brasileiro deixar de observar as garantias legais e constitucionais por ele instituídas aos cidadãos nacionais e estrangeiros. Neste cenário, com razão o Supremo Tribunal Federal, quando, perfilhando tal entendimento, alerta que "não cabe ao Poder Judiciário, no exercício do controle jurisdicional da exegese conferida pelo Legislador a uma garantia constitucional, simplesmente substituí-la pela sua própria interpretação da Constituição" (Brasil, 2019c, p. 186).

Não se pode desconsiderar, partindo de tal lógica, que é incontestável a distinção entre a capitulação legal, utilidade e destinação do princípio do devido processo legal e dos princípios do contraditório e da ampla defesa, porquanto "Os princípios constitucionais precisam, sempre, harmonizar-se, sem haver a exclusão de um pelo outro. [...] Os princípios da ampla defesa e do contraditório são essenciais para o processo justo, logo, para o devido processo legal” (Nucci, 2016, p. 240-242). Constituise, ante a clareza legislativa, a mais eloquente atestação de que tais inconfundíveis franquias constitucionais não compõem uma única e mesma norma jurídica e, sobretudo, a de que a correta interpretação e aplicação jurídicas pressupõe, sempre, "[...] a necessidade do exame individualizado dos demais princípios como meio de concretizá-los no sistema jurídico brasileiro" (Araújo, 2016, p. 107); até porque, cada uma delas, possui o seu respectivo âmbito de proteção, apesar de guardarem entre si estreita relação de interligação e complementariedade, segundo Brasil (2010b \& 2012a); daí porque se tem prelecionado que "[...] o interprete, sempre que possível, deve orientar-se pela exegese mais liberal, atento as tendências do processo civil contemporâneo - calcado nos princípios da efetividade e da instrumentalidade - e a advertência da doutrina de que as sutilezas da lei nunca devem servir para impedir o exercício de um direito" (Brasil, 1992, p. 52).

Deve-se lembrar que, com o regime inaugurado pela Carta Política do Brasil/1988 e a superveniente entrada em vigor

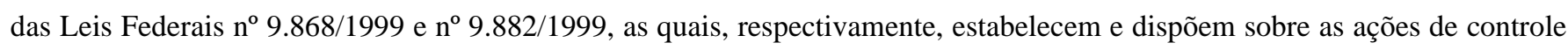
abstrato de constitucionalidade, as leis ordinárias com as sucessivas e relevantes alterações legislativas que, no plano legal, conformam o sobreprincípio do devido processo legal e os subprincípios do contraditório e da ampla defesa dentro da moldura normativa preconizada pelo artigo $5^{\circ}$, incs. LIV e LV, da Magna Carta Federal, nomeadamente o artigo 18, incs. IV e V, do Decreto-Lei no 667/1969; artigo 59 da Lei Federal no 7.210/1984; artigo 143 da Lei Federal no 8.112/1990; artigos 86, § 2 $2^{\circ}$, e 87, $\S 2^{\circ}$ e $3^{\circ}$, da Lei Federal $n^{\circ}$ 8.666/1993; artigo 10 da Lei Federal no 8.745/1993; artigos $1^{\circ}$, caput, e $2^{\circ}$, caput, da Lei Federal $n^{\circ}$ 9.784/1999; artigo $8^{\circ}$, caput, da Lei Federal $n^{\circ} 12.846 / 2013$; e artigo $2^{\circ}$, parágrafo único, da Lei Federal $n^{\circ}$ 12.990/2014, não foram, por meio desses instrumentos jurídicos, contestadas perante o Colendo Supremo Tribunal Federal para fins de, mediante controle concentrado de constitucionalidade, obter-se a declaração de constitucionalidade ou de inconstitucionalidade, inclusive a de interpretação conforme a Constituição Federal/1988, a confirmar, desse modo, a correta distinção que essas normas positivas internas fazem entre tais garantias fundamentais, eis que, cada uma delas, possui o seu âmbito de proteção.

Aduz, em reforço a todas as considerações acima alinhavadas, que, ante a manifesta constitucionalidade formal e material dessa legislação ordinária que estabelece intrínseca e ontológica diferença entre o sobreprincípio do devido processo legal e os subprincípios do contraditório e da ampla defesa, é de se supor, à luz dos fundamentos e da função vital da teoria do diálogo das fontes (Arts. $1^{\circ}$ e 15 do CPC/2015), que não ocorre a configuração do pressuposto negativo da coisa julgada material entre duas ações confrontadas que tenham, cada uma, veiculado a violação das garantias fundamentais do devido processo legal e do contraditório e da ampla defesa como causas de pedir remota (fundamentos de direito e jurídicos), inclusive porque, consoante se registrou em Brasil (2020a), além da eficácia dos limites objetivos da coisa julgada circunscreverem-se às 
questões decididas, não cabe ao Poder Judiciário, ainda que com as melhores intenções, aperfeiçoar, criar ou aditar as regras legais do sistema jurídico nacional, sob pena de ultrapassar a linha tênue entre julgar, legislar e executar, e, ainda, que desconsiderar as técnicas de decisão, quando o sentido óbvio, notório e imediato da legislação ordinária subjacente, afasta, por completo, a objeção de coisa julgada, representa um formalismo excessivo e desarrazoado que fere todos os princípios do processo civil moderno, cerceando, em última análise, o direito subjetivo público do jurisdicionado de acesso à ordem jurídica justa (Art. $5^{\circ}$, inc. XXXV, da CRFB/1988), então princípio fundamental dos Poderes Institucionais da República Federativa do Brasil, dentre eles o Poder Judiciário, cuja força principiológica, deve ser utilizada como norma diretiva da função judicante.

Como se pode deduzir do texto das leis e da sua interpretação pela doutrina, o princípio do devido processo legal e os subprincípios do contraditório e da ampla defesa por estarem previstos em dispositivos distintos e autônomos, designadamente nos incisos LIV e LV do artigo $5^{\circ}$ da Magna Carta Federal, são independentes entre si, eis que as respectivas naturezas jurídicas e âmbitos de proteção são diversos, de modo que a ofensa a um deles não pressupõe a do outro, sobressaindo evidente, sob esse prisma, que "Toda lei deve ser interpretada dentro do sistema jurídico. Não há interpretação de norma isolada. O Direito forma um conjunto, um todo, que tem como principal fonte a Constituição" (Fontes, 2004, p. 8).

Tendo isso em vista, a conclusão a ser assentada é de que, em contextos como o ora em análise, baseados também na diretriz dos princípios constitucionais, "é a b c, na interpretação das leis, a regra de que na mesma lei, no mesmo Código, na mesma Constituição, cessa o império de qualquer dos seus artigos onde comece o império de outro. Todos imperam em harmonia recíproca. Nenhum foi gerado para vassalo de outro. Nascem com o mesmo direito à vida" (Dória, 1960, p. 828). E, a reforçar, de forma contundente, a distinção marcante e significativa entre eles, é, também, a de que "A eficácia do devido processo legal estará configurada quando presente sua dupla proteção individual, tanto no âmbito material de proteção ao direito de liberdade, cuja supressão exige decisão judicial escrita e fundamentada da autoridade competente (CF, art. $5^{\circ}$, LXI), como no âmbito formal, ao assegurar ao réu paridade total de condições com o Estado-persecutor e plenitude de defesa, visando a impedir o arbítrio do Estado" (Brasil, 2018b, p. 5).

Isso significa, à luz dos parâmetros acima fixados, que "as restrições a direitos fundamentais devem ser interpretadas restritivamente, consoante lição basilar da dogmática de restrição a direitos fundamentais, [...]" (Brasil, 2017), de forma a coibir, assim, os abusos com maior eficácia, até porque, nesse aspecto, austero princípio de hermenêutica proclama que nem a interpretação extensiva nem a analógica se justificam em tema de exceções, sobretudo, quando conferem ou subtraem direito material e ou processual do jurisdicionado (Maximiliano, 1961).

\section{Conclusão}

À guisa de conclusão é importante dizer, com alto grau de certeza, que o princípio do devido processo legal e os princípios do contraditório e da ampla defesa são diferentes tanto no aspecto legal quanto no constitucional e os são porque os seus respectivos âmbitos de proteção divergem entre si, devendo, pois, as Cortes de Sobreposição (STF e STJ), os Tribunais antecedentes e os Órgãos monocráticos do Poder Judiciário brasileiro reconhecerem-na e, sobretudo, aplicarem-na em seus julgados singular ou colegiado, visto que "não se revela lícito, ao Poder Judiciário, atuar na anômala condição de legislador positivo [...]" (Brasil, 2002b, p. 234).

Além disso, frise-se que "não se interpreta o direito em tiras; não se interpreta textos normativos isoladamente, mas sim o direito, no seu todo [...]" (Brasil, 2012b, p. 208); e, em igual medida, no teor de Brasil (2018a, p. 13), reitera-se que "[...] a interpretação da Constituição não pode ser realizada de maneira fatiada, [...]”, o que, para além de qualquer dúvida razoável, séria e fundada, demanda, diante das circunstâncias de cada caso concreto, uma interpretação lógico-sistemática dos incisos LIV e LV do Estatuto Fundamental do Estado brasileiro e das normas positivas domésticas que os refletem no plano estritamente legal. 
Dessa maneira, atentando-se à natureza tridimensional do contraditório, deve-se considerar a extensão do conceito de defesa, notadamente a partir da qualificação constitucional que lhe confere amplitude no campo processual. Assim, a "ampla defesa é a oportunidade dada ao réu para trazer para dentro dos autos todos os elementos de defesa esclarecedores da verdade, durante todo o decorrer do procedimento" (Pagliarini, 2001, p. 466); razão por que se diferencia do contraditório, que apresenta o caráter dialético do processo, com base no qual as partes terão ciência de todos os expedientes processuais, bem como lhes será dada a oportunidade de influir significativamente no convencimento do juiz por intermédio de manifestações tempestivas no curso do procedimento.

Por fim, a título de pesquisas futuras, recomenda-se a análise de outros direitos e garantias individuais que devem ser interpretados conjuntamente, respeitando-se, assim, a unidade da Constituição, na medida em que se efetiva a integralidade dos enunciados normativos superiores ao patamar da legalidade ordinária. Dessa maneira, estudos científicos qualitativos nesse sentido poderiam dispor sob lume um direito fundamental distinto daqueles arrolados no elenco do art. $5^{\circ}$, como forma de ressaltar a abrangência de disposição do Texto Maior, ao mesmo tempo em que se estabeleceria a reflexão teórica de que a alocação esparsa de dispositivos fundamentais não inviabiliza a efetividade dos comandos constitucionais destinados à proteção jurídica dos jurisdicionados.

\section{Referências}

Araújo, F. C. de. (2016). Curso de Processo Civil: parte geral. Malheiros.

Brasil. Supremo Tribunal Federal. (1973). Recurso Extraordinário $n^{o}$ 71284/SP. Rel. Min. Aliomar Baleeiro, Primeira Turma. https://redir.stf.jus.br/paginadorpub/paginador.jsp?docTP=AC\&docID=167119

Brasil. Superior Tribunal de Justiça. (1992). Recurso Especial $n^{o}$ 11834/PB. Rel. Min. Sálvio de Figueiredo Teixeira, Quarta Turma. https://scon.stj.jus.br/SCON/GetInteiroTeorDoAcordao?num_registro=199100118338\&dt_publicacao=30/03/1992

Brasil. Supremo Tribunal Federal. (1995). Agravo de Instrumento $n^{o} 152676$ AgR/PR. Rel. Min. Maurício Corrêa, Segunda Turma. https://redir.stf.jus.br/paginadorpub/paginador.jsp?docTP=AC\&docID=276888

Brasil. Supremo Tribunal Federal. (2002a). Agravo de Instrumento $n^{o} 290136$ AgR/SP. Rel. Min. Carlos Velloso, Segunda Turma. https://redir.stf.jus.br/paginadorpub/paginador.jsp?docTP=AC\&docID=299856

Brasil. Supremo Tribunal Federal. (2002b). Recurso Extraordinário no 200844 AgR/PR. Min. Rel. Celso de Mello, Segunda Turma, DJ em 16/08/2002 p. 00092. https://redir.stf.jus.br/paginadorpub/paginador.jsp?docTP=AC\&docID=330565

Brasil. Supremo Tribunal Federal. (2009). Recurso Extraordinário no 590779/ES. Rel. Min. Marco Aurélio, Primeira Turma. https://redir.stf.jus.br/paginadorpub/paginador.jsp?docTP=AC\&docID=583915

Brasil. Supremo Tribunal Federal. (2010a). Habeas Corpus $n^{o}$ 84078/MG. Rel. Min. Eros Grau, Tribunal Pleno. https://redir.stf.jus.br/paginadorpub/paginador.jsp?docTP=AC\&docID=608531

Brasil. Superior Tribunal de Justiça. (2010b). Agravo Regimental no Recurso Especial no 802252/RS. Rel. Min. Celso Limongi [Desembargador convocado do TJ/SP], Sexta Turma. https://scon.stj.jus.br/SCON/GetInteiroTeorDoAcordao?num_registro=200502016069\&dt_publicacao=23/08/2010

Brasil. Tribunal Regional Federal da $1^{\text {a }}$ Região. (2011). Apelação Civil $n^{o}$ 2003.01.99.017213-4/MG. Rel. Juiz Fed. Leão Aparecido Alves, Sexta Turma Suplementar. https://arquivo.trf1.jus.br/PesquisaMenuArquivo.asp?p1=200301990172134\&pA=200301990172134\&pN=116087320034019199

Brasil. Superior Tribunal de Justiça. (2012a). Recurso Especial $n^{o}$ 1307407/SC. Rel. Min. Mauro Campbell Marques, Segunda Turma. https://scon.stj.jus.br/SCON/GetInteiroTeorDoAcordao?num_registro=201200287073\&dt_publicacao=29/05/2012

Brasil. Supremo Tribunal Federal. (2012b). Arguição de Descumprimento de Preceito Fundamental $n^{\circ}$ 101/DF. Rel. Min. Cármen Lúcia, Tribunal Pleno. https://redir.stf.jus.br/paginadorpub/paginador.jsp?docTP=AC\&docID=629955

Brasil. Supremo Tribunal Federal. (2014). Recurso Extraordinário $n^{o}$ 355856/SC. Rel. Min. Marco Aurélio, Primeira Turma. https://redir.stf.jus.br/paginadorpub/paginador.jsp?docTP=TP\&docID=6258704

Brasil. Tribunal Superior Eleitoral. (2017). Interpretação de normas. Recurso Especial $\mathrm{n}^{\mathrm{o}} 21321 / \mathrm{MG}$, Rel. Min. Luiz Fux. https://temasselecionados.tse.jus.br/temas-selecionados/inelegibilidades-e-condicoes-de-elegibilidade/parte-ii-temas-diversos-sobre-inelegibilidades-econdicoes-de-elegibilidade/interpretacao-das-normas

Brasil. Supremo Tribunal Federal. (2018a). Agravo Regimental em Mandado de Segurança $n^{o} 33939$ AgR/DF. Rel. Min. Luiz Fux, Tribunal Pleno. https://redir.stf.jus.br/paginadorpub/paginador.jsp?docTP=TP\&docID=14845768 
Research, Society and Development, v. 10, n. 15, e426101523090, 2021

(CC BY 4.0) | ISSN 2525-3409 | DOI: http://dx.doi.org/10.33448/rsd-v10i15.23090

Brasil. Supremo Tribunal Federal. (2018b). Habeas Corpus $n^{\circ}$ 149439/DF. Rel. Min. Alexandre de Moraes, decisão monocrática. https://redir.stf.jus.br/paginadorpub/paginador.jsp?docTP=TP\&docID=748738316

Brasil. Supremo Tribunal Federal. (2019a). Ação Direta de Inconstitucionalidade nº 6193/MT. Rel. Min. Alexandre de Moraes, decisão monocrática, DJe-170 em 05/08/2019. http://portal.stf.jus.br/processos/downloadPeca.asp?id=15340677276\&ext=.pdf

Brasil. Superior Tribunal de Justiça. (2019b). Recurso Especial $n^{o}$ 1670907/RS. Rel. Rel. Min. Herman Benjamin, Segunda Turma. https://scon.stj.jus.br/SCON/GetInteiroTeorDoAcordao?num_registro=201701080560\&dt_publicacao=06/11/2019

Brasil. Supremo Tribunal Federal. (2019c). Ação Declaratória de Constitucionalidade $n^{o}$ 43/DF. Min. Rel. Marco Aurélio, Tribunal Pleno. https://redir.stf.jus.br/paginadorpub/paginador.jsp?docTP=TP\&docID=754357342

Brasil. Supremo Tribunal Federal. (2020a). Ação Direta de Inconstitucionalidade $n^{o} 6299$ MC/DF. Rel. Min. Luiz Fux, decisão monocrática. http://portal.stf.jus.br/processos/downloadPeca.asp?id=15342203609\&ext=.pdf

Brasil. Supremo Tribunal Federal. (2020b). Recurso Extraordinário $n^{o}$ 1.169.289/SC. Rel. Min. Marco Aurélio, Tribunal Pleno. https://redir.stf.jus.br/paginadorpub/paginador.jsp?docTP=TP\&docID=753146129

Cintra Júnior, D. A. D. (2012). O devido processo legal e a defesa efetiva. Doutrinas Essenciais Processo Penal, 1, 95-101.

Dória, A. de S. (1960). Direito Constitucional (Comentários à Constituição de 1946). Editor Max Limonad, v. 4.

Fontes, R. B. (2004). Decadência e prescrição administrativas. Revista Consulex, 18 (37), 8.

Freide, R. (2014). Do princípio constitucional do contraditório: vertentes material e formal. Revista dos Tribunais, 946, 113-124.

Jayme, F. G. (2014). O princípio do contraditório no projeto do novo código de processo civil. Revista de Processo, 227, 335-359.

Lima, M. R. O. (1999). Devido processo legal. Sergio Antonio Fabris Editor.

Lopes, M. A. R. (1996). Ampla defesa, contraditório e defesa efetiva. Revista dos Tribunais, 725, 459-470.

Maximiliano, C. (1961). Hermenêutica. Rio de Janeiro: Livraria Freitas Bastos.

Mello, S. P. M. P. (2017). Metodologia da pesquisa em direito. SESES.

Mendes, G. F. (2012). Curso Direito Constitucional. Saraiva.

Nucci, G. de S. (2016). Constituição Federal Comentada. Forense.

Oliveira, L. S. de. (2020). Contraditório. Revista de Processo, 302, 17-38.

Pagliarini, A. C. (2001). Contraditório e ampla defesa: direitos humanos e principais garantias processuais. Revista dos Tribunais, 784, 459-473.

Prodanov, C. C. \& Freitas, E. C. de. (2013). Metodologia do trabalho científico: métodos e técnicas de pesquisa e do trabalho acadêmico. Novo Hamburgo: Feevale.

Tucci, R. L. (1993). Devido processo penal e alguns dos seus mais importantes corolários. Revista da Faculdade de Direito, Universidade de São Paulo, 88 (1), 463-484.

Wambier, L. R. (2005). Curso avançado de processo civil: teoria geral do processo de conhecimento. Revista dos Tribunais. 